Archived version from NCDOCKS Institutional Repository http://libres.uncg.edu/ir/asu/

\title{
Appalachl̈an
}

B O O N E, N O R T H C A R O L I N A

\section{Virtual And Valued: A Review Of The Successes (And A Few Failures) Of The Creation, Implementation, And Evaluation Of An Inaugural Virtual Conference And Monthly Webinars}

\author{
By: Mollie Peuler and Kelly C. McCallister
}

\begin{abstract}
Planning and implementing online professional development opportunities is challenging but attainable. This paper explains how a group of librarians from different institutions worked to plan, market, implement, and evaluate monthly webinars as well as an inaugural online conference, despite never meeting in person. The web conferences began in-state and grew to include presenters and attendees from across the nation. A review of available web-conferencing technologies will be provided, including free and open-source options. This paper includes details about the planning process, including subcommittee collaborations, social media marketing, and day-of logistics. Failures during event planning and execution — and tips to avoid them — will be discussed, as well as next steps looking forward.
\end{abstract}

Peuler, M. and K. C. McCallister (2018). "Virtual and Valued: A Review of the Successes (and a Few Failures) of the Creation, Implementation, and Evaluation of an Inaugural Virtual Conference and Monthly Webinars." Journal of Library \& Information Services in Distance Learning: 1-11. https://doi.org/10.1080/1533290X.2018.1499240. Publisher version of record available at: https://www.tandfonline.com/doi/full/10.1080/1533290X.2018.1499240 


\title{
Virtual and Valued: A Review of the Successes (and a Few Failures) of the Creation, Implementation, and Evaluation of an Inaugural Virtual Conference and Monthly Webinars
}

\author{
Mollie Peuler ${ }^{a}$ and Kelly C. McCallister ${ }^{b}$ \\ aHagemeyer Learning Resource Center, Central Piedmont Community College, Charlotte, North

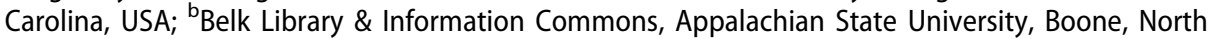 \\ Carolina, USA
}

\begin{abstract}
Planning and implementing online professional development opportunities is challenging but attainable. This paper explains how a group of librarians from different institutions worked to plan, market, implement, and evaluate monthly webinars as well as an inaugural online conference, despite never meeting in person. The web conferences began in-state and grew to include presenters and attendees from across the nation. A review of available web-conferencing technologies will be provided, including free and open-source options. This paper includes details about the planning process, including subcommittee collaborations, social media marketing, and day-of logistics. Failures during event planning and execution-and tips to avoid themwill be discussed, as well as next steps looking forward.
\end{abstract}

\section{KEYWORDS}

Webinars; professional development; library association; web conferencing; academic librarians

\section{Introduction}

The North Carolina Library Association (NCLA) is a statewide organization representing the needs and interests of diverse North Carolina libraries and library professionals. It focuses on topics that include information literacy, intellectual freedom, and general information services. To effectively serve the needs of such a diverse body of professionals, there are over ten sections and roundtables, including the College and University Section (CUS) (NCLA, 2017a). The CUS represents college and university librarians and other professionals employed primarily by academic libraries. Established in 1978, the objectives of the organization are to unite North Carolina college and universities, to provide opportunities for discussion and activities which will further professional growth, to promote and develop improved library service, and to seek to fulfill the objectives of the NCLA and the Association of College \& Research Libraries (NCLA, 2017a). 
Prior to 2016, CUS offered several opportunities for robust professional development activities, such as one-day conferences and face-to-face workshops for their members. Participants voiced concerns about the cost of such opportunities both in registration fees and travel as many members were hours away from the designated location. When the new executive board began their two-year tenure in 2016, they began to explore online options as a mechanism to offer travel and registration-free professional development opportunities to their 125+ members.

For academic librarians, professional development offers additional training that may not have been provided in library school or from on the job training (Pan \& Hovde, 2010). For many academic librarians, it is part of the job description to stay current on new trends and technological advancements and to present and publish on topics of librarianship (Cary, 2001). As the discipline constantly changes with the unceasing advancement of technological capabilities, librarians are expected by their institutions to keep up with these changes with little or no additional funding for training (Coiffe, 2012; Wyatt, 2007). Those who have a professional development budget are encouraged to travel to conferences or attend high cost online and face-to-face workshops presented by various professional associations. For those with little or no budget, free professional development opportunities are typically hard to find. Also, providing "free" face-to-face professional development can be very expensive if one considers the costs of hosting a speaker, renting a venue, supplying refreshments, and printing handouts, agendas, and programs. The cost is perhaps the main reason behind the increase of online professional development opportunities, such as webinars (Coiffe, 2012; Fink, 2013; Wyatt, 2007).

The high cost of offering face-to-face options was analyzed by the CUS executive board when examining possible professional development opportunities for members. In 2016, the CUS executive board sent out a survey to their members to determine which types of events and professional development opportunities would be most beneficial. Over 95\% responded that they would be interested in attending and/or presenting at free virtual webinars and conferences (College \& University Section, 2016). The survey results thus demanded that the CUS executive board review various types of web conferencing systems available to determine the most feasible platform for offering online opportunities to CUS members.

\section{Web conferencing systems review}

There are countless web conferencing options available, ranging from free to prohibitively expensive. The first step in choosing a web conferencing system is taking inventory of institutional needs and using that list to guide 
decision-making. For example, one may consider the approximate number of people that will attend offered webinars since many conferencing systems have a limit on how many individuals can attend at one time. Systems also vary widely in their specific features, such as the type of statistical reporting, automatic messaging, recording, and interactivity. It's also worth noting that many colleges and universities may already pay for a web conferencing system that is free and accessible for use in providing professional development opportunities.

The CUS executive board explored well known webinar systems and reviewed their options and usability. After careful analysis, they decided on a system that would allow for $200+$ users, offered a video option and included a visible chat for interactive participation. Assessment options such as pre-registration with contact information, automated, edited follow-up emails to include links to evaluations and surveys and recordable options were also identified and investigated.

Appendix A represents the results of the review and includes the following information: cost, maximum number of attendees, specific features, and contact information. Zoom was chosen as the system of use for CUS professional development opportunities for its function, maximum number of attendees (500), and low cost.

\section{CUS webinar Wednesday}

Recognizing the CUS member's need for accessible online content, the CUS executive board identified opportunities for expanded online teaching and learning. The idea for shorter, content-rich webinars- called CUS Webinar Wednesday-was born. Research indicates that an interactive webinar with a maximum length of one hour is ideal for learning (Zoumenou et al., 2015). With this in mind, CUS Webinar Wednesday is intended to be shorter presentations, with a maximum presentation time of 40 and 20 minutes for questions. Though hosted by the CUS section, the webinars are an engagement opportunity for all types of librarians and library staff, including library students, professional library staff, academic librarians, public librarians, and others. Given this diverse audience, the webinars were crafted to cover a wide range of topics, including but not limited to distance library services topics. Held at least once a month, the webinars took place on Wednesdays at presenters' time preference.

The name CUS Webinar Wednesday was picked for the ease of scheduling as well as marketing. A consistent day of the week allowed attendees to eventually expect the webinars, and "Webinar Wednesday" seemed like an ideal name for marketing on the CUS website, social media, and listservs. Per request, each webinar was recorded and archived on the CUS web 
page, http://www.nclaonline.org/college-university. Since the first webinar in September 2016, thirteen webinars were presented with over 900 registered US and international attendees. To date, over 959 views have been noted on the archived North Carolina Library Association YouTube channel where the recordings are stored (NCLA, 2017b).

\section{CUS one-day virtual conference}

Riding on the success of the CUS Webinar Wednesday series, the CUS executive board opted to offer a virtual one-day conference for its members. In order to reach a wider audience and to provide concurrent virtual sessions, the CUS executive board collaborated with members of Appalachian State University's Center for Academic Excellence and librarians from the Belk Library \& Information Commons. Additionally, a call for CUS member volunteers to help plan and organize the one-day virtual conference was released and volunteers were recruited and then assigned, per their request, to one or more of a variety of planning subcommittees. The volunteers were located throughout North Carolina and collaborated entirely online. Volunteers used their own institution's web conferencing system to meet and used the collaborative features of Google Apps for Education to create content from a distance. The following is a summary of the work completed by each sub-committee.

\section{Registration/agenda committee}

The registration subcommittee used Google Forms to create the conference registration form that would be pushed out via the marketing subcommittee. It was decided that the registration form would be as simple as possible and collect some basic intake information that would give the CUS conference planning committee an overview of the type of librarians attending. This subcommittee was also tasked with creating the conference agenda and schedule. It was determined that the conference would run from 9:30 AM to 4:45 PM EST. This included a short introduction at the beginning of the virtual conference and three concurrent sessions per 45 minutes, for a total of 17 sessions.

\section{Proposal review}

The proposal subcommittee was responsible for creating the proposal guidelines and the proposal request form, and then reviewing the proposal submissions. Once the guidelines were created, Google Forms was used to create a simple proposal form. The members of the committee created a template and sent out a call for proposals to all relevant library listservs as 
well as corresponding Facebook pages. Once the deadline for submissions passed, the subcommittee met asynchronously to review the submitted proposals. It was determined that since this was the first virtual conference, all of the proposal would be accepted in order to provide a wide range of offerings. Once this decision was made, all of the presenters were contacted and made aware of their acceptance. The proposal review committee would continue to communicate with the presenters leading up to the conference, to confirm presentation times and presentation description details.

\section{Marketing committee}

The marketing subcommittee was tasked with creating marketing materials to be used for branding the conference and soliciting presenters and eventually attendees. To distinguish the CUS One-Day Virtual Conference from the larger governing body of NCLA, the marketing subcommittee decided to create a conference logo (Appendix B) that could be used for all marketing materials moving forward. However, care was taken that the logo complemented the wider NCLA; to that end, the logo incorporated the NCLA logo and colors. The logo also featured the theme of international collaboration and learning since the goal was for the conference to be attended internationally. The logo was added to the NCLA CUS One-Day Virtual Conference website and was also given to other committees to incorporate into Google Forms that were created to solicit presenters. The next step for the marketing committee was to solicit presenters for the virtual conference. Using the list created by the technology committee, the marketing committee created a list of library listserv email addresses and Facebook pages to market the opportunity. The goal was for the conference to be farreaching. With this in mind, library organizations across the nation were considered in regards to marketing.

\section{Technology committee}

The technology committee was responsible for solving any technical issues with the webinars before and on the day of the conference. The virtual conference itself was hosted and run by volunteers from the CAE and Belk Library at the Appalachian State University campus. Members of the committee also provided training and practice per request, to any presenters that were new to online presenting or Zoom software itself, prior to the day of the conference. A committee member was assigned to each webinar as a facilitator and tech support to allow the presenter to focus on content and presentation. They were available to assist attendees in the webinar who were having technical problems or questions and to record each 


\section{Overall Conference Rating:}

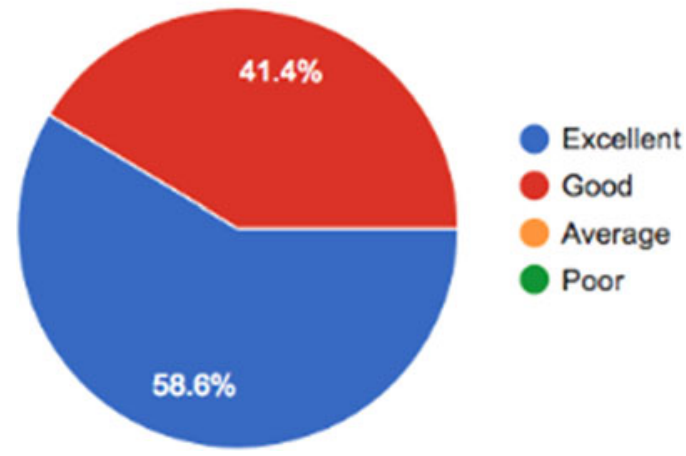

Figure 1. One-Day Virtual Conference rating. Citation (McCallister \& Natale, 2017).

session. It was of great importance for the CUS executive board that technology not become a barrier but rather a bridge in attending and participating in the conference.

The CUS One-Day Virtual Conference was a huge success and served as a more than adequate substitute for the usually offered in-person conference. Figure 1 reflects data collected from the follow up survey concerning the overall conference rating.

One of the major advantages of the online conference was the cost savings for all parties involved. There was no registration or attendance fees for librarians or presenters. Table 1 shows the cost comparison of the face to face 2014 conference compared to the 2017 virtual conference. Venue rentals fees, refreshments, and other miscellaneous items accrue a large cost that fortunately were not necessary for an online conference.

\section{Assessment}

The 2016-2017 online professional development opportunities were evaluated by the CUS executive board and it was determined that while the outcomes were primarily successful, there were a few failures. In regards to assessment, a follow up survey and links to the archived sessions and materials was sent to all registered attendees after each webinar. Data collected from the survey was used to adapt the online series to suit the needs of the attendees and to suggest relevant topics of interest for future webinars. An example was offering the webinars at 2:00 pm EST per the request of the west coast librarians who wished to attend at a reasonable hour in their time zone.

The comments and suggestions section of the survey was overwhelmingly positive as attendees noted that they welcomed both the learning opportunities and the chance to present their expertise at no cost and travel. Many remarked their appreciation that these opportunities were available (and archived) to all library employees regardless of specialization, affiliation, or 
Table 1. Cost Comparison of 2014 and 2017 One-day Conferences.

\begin{tabular}{ll}
\hline 2014 & \multicolumn{1}{c}{2017} \\
\hline Budget: $\$ 2,036$ & Budget: $\$ 268.95$ \\
Registration: $\$ 20-\$ 40$ & Registration: $\$ 0$ \\
Attendance: 125 & Attendance: $200+$ \\
\hline
\end{tabular}

physical location. Additional comments suggested a list of relevant topics to offer in future webinars such as open source textbooks and makerspaces (whose scheduled webinars revealed a high number of registered attendees). The suggestions mirrored what is up and coming in the library literature and it was considered a great success to provide a free virtual introduction and training for librarians.

The survey was also a useful means of collecting demographic data of the attendees. Figure 2 shows the demographics of the librarians who participated in the webinars as attendees or presenters. It is interesting to note that the webinars attracted $41 \%$ senior librarians and $12 \%$ who classified themselves as "Other."

Figure 3 shows the webinar attendees' library specialty classifications. The largest number of attendees were Reference/Instruction librarians at $34 \%$, which was expected due to the instruction-based topics offered. Additionally, there were a remarkably high number of attendees in the IT, cataloging, and special collections fields.

The most surprising statistic was the geographic reach of the webinar attendees. Over 53\% were members of NCLA including $28 \%$ who were also members of CUS, and the rest were from across institutions across the United States, including librarians from Canada, Mexico, and Trinadad \& Tobago.

As previously mentioned, all sessions from the series and conference were recorded and archived on the CUS website. Analytics from both the website and YouTube channel reveal a large number of views and hits weeks after the scheduled webinars. Archiving on the YouTube channel also provided the opportunity for viewers to leave comments and ask questions which appear on the site.

Additionally, the CUS executive board has received invites to collaborate with other sections, such as the newly formed Distance Learning Section, to work together on future virtual conferences.

\section{Successes}

The first offered CUS Webinar Wednesdays had few (no more than 20) attendees. In order to increase popularity and the numbers of attendees, the CUS executive board extended the monthly webinar series and, later, the one-day virtual conference beyond the virtual borders of North Carolina. This was accomplished by soliciting attendees and presenters 


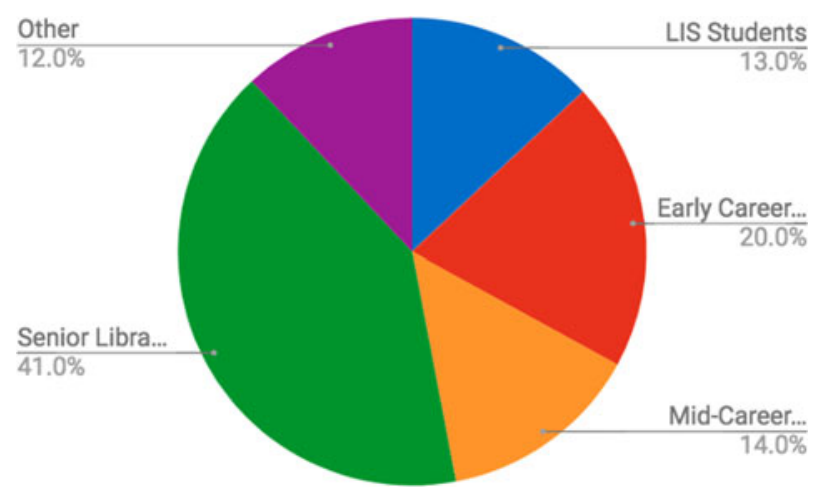

Figure 2. Webinar attendee demographics. Citation (McCallister \& Natale, 2017).

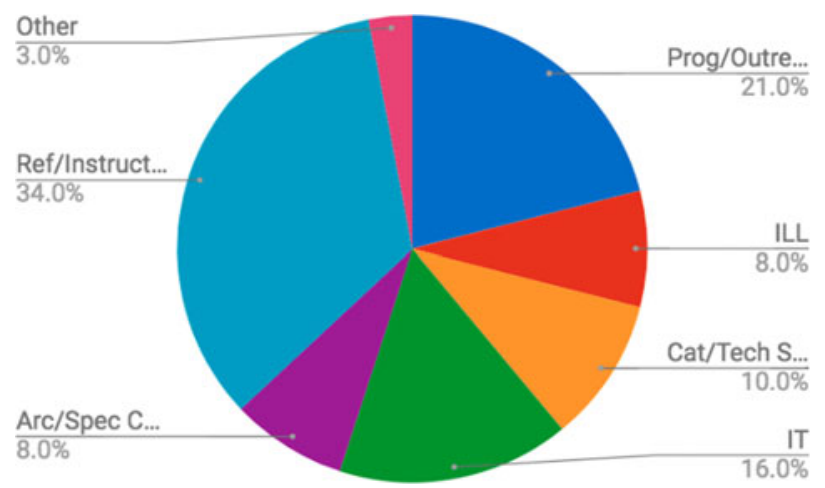

Figure 3. Webinar attendees library specialities. Citation (McCallister \& Natale, 2017).

from several of the American Library Association and Association of College \& Research Libraries listservs, NCLA social media outlets, and a small mention in the "News from the Field" section in the College \& Research Libraries News (Free, 2017). What was perceived at first as a "failure" quickly became a success as the numbers of registered attendees and call for proposals tripled. There was also a noted increase of views from the archived webinars on the NCLA YouTube channel.

\section{Failures}

With great success comes several opportunities for failures and opportunities for improvement. Collaborating at a distance is easier with the advent of cloud technology, such as Google Apps for Education, but this distance can also lead to errors if the appropriate editing and double-checking does not take place. For example, when the virtual conference registration Google Form went out, the edit link was included-meaning that interested parties were actually editing the form rather than being able to register. A new email with the correct link needed to be sent out and all of the social 
media marketing needed to be updated. This was a manageable error, but in the future the committee must pay closer attention to all manners of details, such as the share settings on conference documents.

The scheduling of the one-day virtual conference was also an area of improvement. Since the committee accepted all proposals, some of the sessions were scheduled later in the day on Friday. Attendance definitely tapered off at this point. In the future, the committee will be more critical of proposal and select fewer of them so that attendance can remain high. While not ideal, these failures confirmed the effectiveness of the CUS Executive committee's evaluation process. The committee will continue to use the qualitative data of anecdotal assessment and the quantitative data of surveys to grow and improve an overall successful online professional development series.

\section{Next steps}

After the stage of initial assessment was complete, the CUS executive board spent time considering next steps and the future of the CUS Webinar Wednesday series and one day-virtual conference. As the terms of many of the executive board were ending, they considered whether or not the webinar series could be transferred to a NCLA section with more of an online and distance focus. NCLA had recently approved the formation of a new section, Distance Learning Section, and the online webinars would be transferred to and managed by this new section. The hope was that this transfer would allow the focus to remain on distance and online library services, with an emphasis on instructional library services, and yet also encourage space to meet the needs of more diverse library professionals such as collection managers, archivists, and public and school librarians. The Distance Learning Section could potentially serve a more diverse population of librarians, allowing for a larger assortment of webinars.

\section{References}

Cary, S. (2001). Faculty rank, status, and tenure for librarians: Current trends. College \& Research Libraries News, 62(5), 510-520.

Coiffe, D. J. (2012). Webinars: Continuing education and professional development for librarians. Journal of the Leadership \& Management Section, 9(1), 37-48.

College \& University Section (2016). NCLA College and University Section Events Poll. Retrieved from https://docs.google.com/forms/d/e/1FAIpQLScM49ekjhDLa5GokZG gXIXpGKTCxZE1sahAdCnwxNZ6hJvupw/viewform?usp=embed_facebook

Fink, M. P. (2013). Your key to professional development: YALSA webinars a great perk for members. Young Adult Library Services, 11(4), 8.

Free, D. (2017). News from the field. College \& Research Libraries News, 78(6), 294-296.

McCallister, K., \& Natale, J. (2017, October). NCLA 2017 conference presentation, offering virtual conferences: Technology, management \& assessment. Winston-Salem, NC. 
North Carolina Library Association (2017a). Historical information. Retrieved from http:// www.nclaonline.org/organization/ncla-handbook/appendix-historical-information.

North Carolina Library Association (2017b). North Carolina Library Association YouTube Channel. Retrieved from https://www.youtube.com/user/NCLibraryAssociation.

Pan, J., \& Hovde, K. (2010). Professional development for academic librarians: Needs, resources, and administrative support. Chinese Librarianship, (29), 7.

Wyatt, E. D. (2007). Spreading the word about school libraries: Using webinars as vehicles for professional development. Educational Media \& Technology Yearbook, 32, 88-97.

Zoumenou, V., Sigman-Grant, M., Coleman, G., Malekian, F., Zee, J. M. K., Fountain, B. J., \& Marsh, A. (2015). Identifying best practices for an interactive webinar. Journal of Family \& Consumer Sciences, 107(2), 62-69.

\section{Appendix A Review of Web Conferencing Systems}

\begin{tabular}{|c|c|c|c|c|}
\hline $\begin{array}{l}\text { Web } \\
\text { Conferencing System }\end{array}$ & $\begin{array}{l}\text { Maximum \# } \\
\text { of attendees }\end{array}$ & Features & Cost & Contact info \\
\hline $\begin{array}{l}\text { Adobe } \\
\text { Connect Webinars }\end{array}$ & 100 & $\begin{array}{ll}\text { - } & \text { Audio/video } \\
& \text { conferencing } \\
\text { - } & \text { Analytics } \\
\text { - } & \text { Breakout rooms } \\
\text { - } & \text { Chat } \\
\text { - } & \text { Recording } \\
\text { - } & \text { Screen sharing } \\
\text { - } & \text { White board }\end{array}$ & $\$ 130$ per month & $\begin{array}{l}\text { http://buyconnect. } \\
\text { adobe.com/store/ } \\
\text { adbecnn/Content/ } \\
\text { pbpage. } \\
\text { LandingPage\#info- } \\
\text { webinar }\end{array}$ \\
\hline WebEx Premium 200 & 200 & $\begin{array}{ll}\text { - } & \text { Audio/video } \\
\text { conferencing } \\
\text { - } & \text { Recording, } \\
\text { - } & \text { Screenshare } \\
\text { - } & \text { Whiteboard }\end{array}$ & $\$ 39$ per month & $\begin{array}{l}\text { https://www.webex. } \\
\text { com/pricing/ } \\
\text { index.html }\end{array}$ \\
\hline GoToWebinar Starter & 100 & $\begin{array}{ll}\text { - } & \text { Audio/video } \\
\text { - } & \text { Annferencing, } \\
\text { - } & \text { Automatics emails } \\
\text { - } & \text { Chat } \\
\text { - } & \text { Polls } \\
\text { - } & \text { Recording }\end{array}$ & $\$ 89$ per month & $\begin{array}{l}\text { https://www.goto- } \\
\text { meeting.com/webi- } \\
\text { nar/pricing }\end{array}$ \\
\hline Zoom & $50-500$ & $\begin{array}{ll}\text { - } & \text { Audio/video } \\
\text { - } & \text { conferencing } \\
\text { - } & \text { Analytics } \\
\text { - } & \text { Chat } \\
\text { - } & \text { Polls } \\
\text { - } & \text { Recording }\end{array}$ & $\begin{array}{l}\text { Free-\$19.99 } \\
\text { per month }\end{array}$ & $\begin{array}{l}\text { https://zoom. } \\
\text { us/pricing }\end{array}$ \\
\hline Google Hangouts & 25 & $\begin{array}{ll}\text { - } & \text { Audio/video } \\
\text { conferencing } \\
\text { - }\end{array}$ & Free & $\begin{array}{l}\text { https://hangouts.goo- } \\
\text { gle.com/ }\end{array}$ \\
\hline Skype (Basic) & 25 & $\begin{array}{l}\text { - } \quad \text { Audio/video } \\
\text { conferencing }\end{array}$ & Free & $\begin{array}{l}\text { https://www.skype. } \\
\text { com/en/ }\end{array}$ \\
\hline Apache Open Meeting & 125 & $\begin{array}{ll}\text { - } & \text { Audio/video } \\
& \text { conferencing } \\
\text { - } & \text { Chat } \\
\text { - } & \text { Polls } \\
\text { - } & \text { Recording } \\
\text { - } & \text { Screen sharing }\end{array}$ & Free & $\begin{array}{l}\text { https://openmeetings. } \\
\text { apache.org/index.html }\end{array}$ \\
\hline $\begin{array}{l}\text { Team Viewer } \\
\quad \text { (Business License) }\end{array}$ & 5 & $\begin{array}{ll}\text { - } & \text { Audio/video } \\
\text { - } & \text { Conferencing } \\
\text { - } & \text { Recording } \\
\text { - } & \text { Whiteboard }\end{array}$ & $\$ 41.90$ per month & $\begin{array}{l}\text { https://www.team- } \\
\text { viewer.com/en/pric- } \\
\text { ing/full-comparison/ }\end{array}$ \\
\hline
\end{tabular}


Appendix B CUS One-Day Virtual Conference Logo
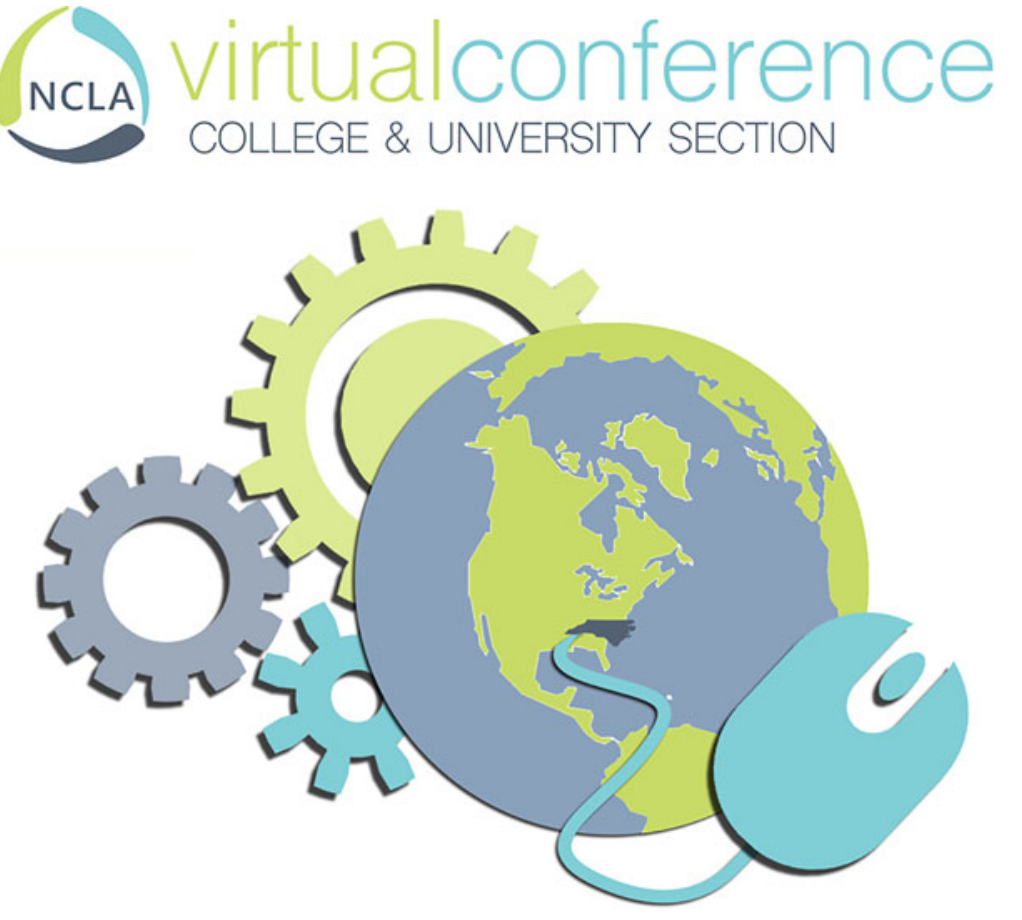